\title{
A Study of Wang Shifu and the Four Great Scholars of Yuan Drama
}

\author{
Zhang Han \\ Department of Drama Version, Central Academy of Drama, Beijing, China
}

Email address:

zhanghanpapers@163.com

\section{To cite this article:}

Zhang Han. A Study of Wang Shifu and the Four Great Scholars of Yuan Drama. International Journal of Literature and Arts. Vol. 7, No. 2, 2019, pp. 49-53. doi: 10.11648/j.ijla.20190702.13

Received: March 7, 2019; Accepted: May 21, 2019; Published: June 15, 2019

\begin{abstract}
Wang Shifu and his Romance of the West Chamber have been highly valued and concerned since ancient times, but Wang Shifu had not been included in the "Four Great Scholars of Yuan Drama". There have been many controversies among the drama writers in Ming and Qing dynasties, and the reasons deserve further exploration. Nevertheless, Wang Shifu's position in the history of drama would not be questioned, nor would it prevent the Romance of the West Chamber from becoming classic. In this paper, by means of comparative study, the author combs the process of Wang Shifu becoming a classic in the context of the history of opera development, and the causes of the classicization of The Romance of the Western Chamber.
\end{abstract}

Keywords: Wang Shifu, Romance of the West Chamber, Four Great Scholars of Yuan Drama

\section{Introduction}

Wang Shifu's Zaju Romance of the West Chamber in Yuan Dynasty had always been highly praised. In the early Ming Dynasty, Jia Zhongming 贾仲明 called it the "worldly top" 天下之魁 work, and Zhu Quan's 朱权 Taihe Correct Pronunciation Music Text《太和正音谱》 evaluated it as, a beautiful woman in the flowers ...... The euphemism of the narrative was very sapid by scholars. Once there were great sentences, just like Yuhuan's bathing in Huaqing or Lvzhu's picking lotus in Luopu.

如花间美人......铺叙委婉, 深得骚人之趣。极有佳句, 若玉环之出浴华清, 绿珠之采莲洛浦。

Later, famous scholars such as Xu Wei 徐渭, Wang Shizhen 王世贞 and Tang Xianzu 汤显祖 praised and promoted the Romance of the Western Chamber. However, Wang Shifu, the author of Romance of the Western Chamber, was not one of the four great scholars of Yuan drama. This special and amusive phenomenon in literary history had been aroused many scholars' attention and ponder over. In recent years, the study of Wang Shifu and his Romance of the West Chamber has become a hot topic in the field of drama research, such as

1 Zhu Quan 朱权: Taihe Correct Pronunciation Music Text《太和正音谱》, Integration of Chinese Classical Dramas Works 《中国古典戏曲论著集成》, China Drama Publishing House 中国戏剧出版社, 1959, Vol. 3, p. 14.
Du Juan's "The Adaptation and Inheritance of Beijing Opera The Story of the West Chamber" [1], Yang Xurong's "A Research into Ji zhi zhai Edition of Readjustment of the North Western Chamber" [2], Lv Mengyun's “An Analysis of the Main Female Characters in The Story of the Western Chamber" [3], etc. The author also tried to explore reasons from the relevant literature.

\section{Naissance of "Four Great Scholars of Yuan Drama" and Absence of Wang Shifu}

The saying of "the four scholars of Yuan drama" originated from a passage in Zhongyuan Phonology《中原音韵》 written by Zhou Deqing 周德清:

The prosperity of Yuefu, its preparation and difficulty were not at present. Its prosperity was that of the gentry and the singers. Their preparation turned to be a kind of new work made by the Guan, Zheng, Bai and Ma, which rhyme was in harmony with the sound of nature and words can be spoken in the world. Words were fluent and graceful, the rhyme promoted the tone. The description of loyalty and filial piety was supplementary to the world by loyal and filial piety during their narration. The difficulty lied in six words and three rhymes which named suddenly listening, a sound, and a shock were also. 
乐府之盛, 之备, 之难, 莫如今时。其盛, 则自搢绅及 闽阎歌咏者众。其备, 则自关、郑、白、马一制新作，韵 共守自然之音, 字能通天下之语, 字畅语俊, 韵促音调; 观其所述，曰忠，曰孝，有补于世。其难，则有六字三韵， “忽听、一声、猛惊”是也。2

Among them, "sudden listening, a sound, and a shock" was from the first play in the Romance of the West Chamber: "I suddenly listened, suddenly shocked, originally it was the flying bird of mock bird." 我忽听一声, 猛惊, 元来是扑刺 刺宿鸟飞腾。In other words, while listing Guan, Zheng, Bai and $\mathrm{Ma}$ as well-known contemporary writers, Zhou Deqing also affirmed the artistic achievements of Romance of the West Chamber from the perspective of phonology [4], but did not name the work and the author's name.

He Liangjun 何良俊, a composer of Ming Dynasty, inherited Zhou Deqing's theory of "Guan, Zheng, Bai and Ma". For the first time, he explicitly introduced the concept of "four scholars of Yuan drama". He pointed out that,

Yuefu of the Yuan Dynasty called Ma Dongli, Zheng Dehui, Guan Hanqing and Bai Renfu as the four scholars. Ma's Ci was sophisticated and charming, Guan's Ci was inspiring but less implicit, and Bai's was rather simple without well-known saying. So Zheng was the first person during them.

元人乐府称马东篱、郑德辉、关汉卿、白仁甫为四大家。 马之词老健而乏姿媚, 关之词激励而少蕴藉, 白颇简淡, 所欠者俊语, 当以郑为第一。3

As a composer who advocated his own characteristics, He Liangjun highly praised Zheng Guangzu, believing that he surpassed the other three and deserved to be the first. For Wang Shifu, he maintained a consistent attitude that although he praised his works as "the hero of genuine $\mathrm{Ci}$-poets with rich talent and sentiment" 才情富丽, 真辞家之雄, he thought that:

The first and last five volumes of Romance of the West Chamber were composed of twenty-one sets of songs, and there were not beyond realm of emotion at all. Why should it be blamed for the repetition of their meanings and confusion of their words?

《西厢》首尾五卷, 曲二十一套, 终始不出一情字, 亦 何怪其意之重复、语之芜类耶 ${ }^{4}$

"All with rouge and gouache" 全带脂粉 did not conform to the rules of drama creation. This view had been accepted by many scholars. Shen Defu 沈德符 said:

Romance of the West Chamber was just about describing emotions. After watching the play, many people hadn't seen a better play than this one, so they praised it as loudly as dogs and believed it's the best song in the world. [5] It's really a frog in the well.

《西厢》到底不过描写情感, 余观此剧, 尽有高出其 上者, 世人未曾遍观, 逐队吠声, 咤为绝唱, 真井蛙之 见耳。

2 Zhou Deqing 周德清: Preface of Phonology in Central Plains 《中原音韵•序》, Integration of Chinese Classical Dramas Works, Vol. 1, pp. 175-176.

3 He Liangjun 何良俊: Siyou Zhai Anthology 《四友斋从说》, $7^{\text {th }}$ year of Wanli in Ming Dynasty, printed by Zhang Zhongyi 明万历七年张仲烦刻本, vol. 37.

4 He Liangjun: Siyou Zhai Anthology, vol. 37.

5 Shen Defu 沈德符: Miscellaneous remarks of Composing Music 《顾曲杂言》,
For "suddenly listening, a sound, and a shock", they didn't regard it as right, "Excellent high-level poets naturally had, here were insect carving skills." 盖胜国词家，高处自有，在 此特其剩技耳。For this reason, they believed that "the four scholars of Yuan Dynasty, Zheng, Ma, Guan and Bai, were inferior to Wang Shifu." 元人以郑、马、关、白为四大家而 不及王实甫, 有以也。6

Wang Shifu did not enter the "four great scholars of Yuan drama", a many of literati in Ming dynasty had doubts and objections, among which Wang Jide, a songsmith, was the most distinguished one. In his Melody, he wrote:

Romance of the West Chamber was bright and beautiful, the Story of Pipa was better in quality, of course. He Yuanlang thought that Romance of the West Chamber was full of rouge and gouache, and the Story of Pipa specialized in learning, but lacked the true qualities. [6] Were there anyone who beyond its distinctive character? It's over.

《西厢》组艳, 《琵琶》修质, 其体固然。何元朗并訾 之, 以为“《西厢》全带脂粉, 《琵琶》专弄学问, 殊寡本 色”。夫本色尚有胜二氏者哉? 过矣。7

He also questioned the traditional saying of "the four great scholars of Yuan drama" and believed that "the world-renowned musicians must be called Guan, Zheng, Bai and $\mathrm{Ma}$, not a patch on Wang, it was not final." 世称曲手, 必曰关、郑、白、马, 顾不及王, 要非定论。" 8 If it was lowered first class and decreased gradually, Wang, Ma, Zheng and Bai." 四人汉卿稍杀一等。第之, 当曰王、马、 郑、白。 ${ }^{9}$ He expressed their high recognition of Wang Shifu. $\mathrm{Xu}$ Fuzuo 徐复祚 also juxtaposed Wang Shifu with Ma, Guan and Zheng, pointing out when talked about the achievements of Yuan people's rhythm: "Try to watch Zaju of Ma, Guan, Wang and Zheng's in Yuan dynasty, was there anything wrong?" 试观元人马、关、王、郑诸公杂剧, 有 是病否? 10

In fact, Wang Shizhen 王世贞 is the most powerful admirer of Romance of the Western Chamber. As the leader of the latter seven men of honour, Wang Shizhen's words and phrases will have a great impact on them. When enumerating the representative writers of Yuanqu, he pointed out that they were excelled in the generation, such as Guan Suanzhai, Ma Dongli, Wang Heqing, Guan Hanqing, Zhang Kejiu, Qiao Mengfu, Zheng Dehui, Gong Dayong, etc., who were talented and fond of rhythm. "而诸君如贯酸斋、马东篱、王和卿、关汉卿、 张可久、乔梦符、郑德辉、宫大用辈, 咸富才情, 兼喜声 律, 以故遂擅一代之长。 ${ }^{11}$ Wang Shifu was ranked third, with

Collection of Research Ocean in Qing Dynasty 清《学海类编》本。

6 Shen Defu: Miscellaneous remarks of Composing Music, Collection of Research Ocean in Qing Dynasty.

7 Wang Jide 王瀷德: Melody 《曲律》, $5^{\text {th }}$ year of Tianqi in Ming Dynasty, printed by Mao Yisui 明天启五年毛以遂刻本, Vol. 3.

8 Wang Jide: Melody, $5^{\text {th }}$ year of Tianqi in Ming Dynasty, printed by Mao Yisui, Vol. 3 .

9 Wang Jide: Ancient Romance of the West Chamber 《古本西厢记》, $11^{\text {th }}$ year of Wanli in Ming Dynasty, Xiang Xue House 明万历四十一年香雪居刻本, Vol. 6.

10 Xu Fuzuo 徐复祚: Collection of Hua Dang Attic 《花当阁丛谈》, transcript by Jie Yue House in Qing Dynasty 清借月山房汇钞本, Vol. 7.

11 Wang Shizhen 王世贞: Views of Literary and Art Circles 《艺苑厇言》, $17^{\text {th }}$ year of Wanli in Ming dynasty, printed by Wulin Qiaoyun Book House 明万历十七年 
Guan, Zheng, Bai and Ma, which had a great impact. He also commented on Romance of the Western Chamber sentence by sentence, which helped to promote the elegant and beautiful language style, and said: "The Northern Works were the last item but one on a theatrical programme by Romance of the Western Chamber." 北曲故以《西厢》压卷。 ${ }^{12}$ This sentence has a far-reaching impact, and has almost become the landmark discourse of the status of Romance of the West Chamber in Ming dynasty. Since then, although there had been another kinds of "five great scholars" or "six great scholars", when discussing the scholars of Yuan drama, Wang Shifu had always been among them, which had something to do with Wang Shizhen's promotion. [7]

\section{Reasons for Wang Shifu's Absence from "Four Great Scholars of Yuan Drama"}

After disappearance of the Qing dynasty, controversy of the "four great scholars of Yuan drama" returned to original point in Wang Guowei's 王国维 era. When he commented on the "four great scholars of Yuan drama" by Drama History in Song and Yuan Dynasties 《宋元戏曲史》, he thought:

Since Ming dynasty, Yuan drama writers had been called Guan, Ma, Zheng and Bai. However, it was better to call Guan, Bai, Ma and Zheng whom were appropriate in terms of their age and attainments. Guan Hanqing was the first person in the Yuan Dynasty because of his dependence and self-made great poems, his language and songs were full of human feelings and the original character. Bai Renfu and Ma Dongli were magnificent, affectionate and limpid. Zheng Dehui was the first-class person with a clear, slender and last a long period turning to be a fragrant and comfortable life.

元代曲家, 自明以来, 称关、马、郑、白。然以其年代 及其造诣论之, 宁称关、白、马、郑为妥也。关汉卿一空 依傍, 自铸伟词, 而其言语曲尽人情, 字字本色, 故当为 元人第一。白仁甫、马东篱, 高华雄浑, 情深文明。郑德 辉清丽芉绵, 自成馨逸, 均不失为第一流。13

This is in line with the reality of political intervention in literature and art in the 20th century, and is also the final word. Despite controversy about the specific selection, because of Wang Guowei's tremendous influence, academic circles basically agree with the saying of "the four great scholars of Yuan drama". Guan, Bai, Ma and Zheng are still preferred textbooks for the history of literature and drama. However, just as Wang Guowei did not deny artistic achievements of Romance of the Western Chamber, the academic circles had always been seen as it differently, giving Wang Shifu the same important position as the "four great scholars". [8]

Although Wang Shifu is not one of the "four great scholars of Yuan drama", his Zaju of Romance of the Western Chamber

武林樵云书舍刻本, Supplement Vol. 3.

12 Wang Shizhen: Views of Literary and Art Circles, Attachment Vol. 3.

13 Wang Guowei 王国维: "Essay of Yuan Drama" in Drama History in Song and Yuan Dynasties 《宋元戏曲史·元剧之文章》, Shanghai Classics Publishing House 上海古籍出版社, 1998, pp. 103-104. has always been a hot topic in the study of drama, and there are plenty of related discussions. This, in fact, stimulated scholars to explore the reasons why Wang Shifu did not belong to the "four great scholars of Yuan drama". First of all, it is Prof. Zhang Renhe from Northeast Normal University, who corrected Wang Shifu's position. His book Discussion on Romance of the Western Chamber combed comments of the four greatest composers of dramas from Yuan Dynasty to Qing Dynasty. It is unfair to exclude Wang Shifu from the great scholars of Yuan drama and it is also not in line with the history of the development of Yuan drama. ${ }^{14}$ Other scholars have explored the specific reasons for Wang Shifu's absence, such as Han Detai's "Wang Shifu and Four Great Scholars in Yuan Drama", ${ }^{15}$ Yan Tingjun's "Discussion on Wang Shifu's Absent of Four Great Scholars in Yuan Drama" ${ }^{16}$ and $\mathrm{Xu}$ Shuai's "Reasons for Speculation on Wang Shifu's Absent of Four Great Scholars in Yuan Drama". ${ }^{17}$ Their conclusions are generally consistent, and there are two main reasons for more discussion: the discount of five books and twenty-one performances of Romance of the West Chamber, which has a special system; controversy between the authors of Romance of the West Chamber, Wang Shifu and Guan Hanqing, with existence of copyright problems.

As the case stands, controversy over the author's rights of Romance of the West Chamber began in the Ming Dynasty, which was far from the time when Zhou Deqing first proposed "the four great scholars of Yuan drama" in the Yuan Dynasty, and was not enough to participate in this discussion. What attracts people's attention is non-standard Zaju system. Undoubtedly, Romance of the West Chamber has own characteristics of "ancient Chuanqi" 旧传奇. Its tortuous stories and interlocking plots made it a long novel with a length of up to five books and twenty-one performances, which was quite different from the standard length of a four-fold Zaju. So many people in Ming and Qing dynasties regarded it as a "Chuanqi", which illustrated the fact that Anthology of Yuan Drama 《元曲选》 did not include Romance of the West Chamber, but the anthology of Sixty Kinds of Songs 《六十种曲》 as a legendary anthology included it. Especially, Romance of the West Chamber does not conform to the general practice of Yuan Zaju in the music system, which is suspected of "breaking styles"破体.

Every singer in Yuan drama was limited to one person, if Mo末 or Dan 旦, then she spoke aside and cannot sing. If singing, it was limited to the introduction; if singing in the

14 Zhang Renhe 张人和: Discussion on Romance of the Western Chamber 《西 厢记》论证, Northeast Normal University Press 东北师范大学出版社, 1995, p. 29.

15 Han Detai 韩德太: "Wang Shifu and Four Great Scholars in Yuan Drama" 《王 实甫之与元曲四大家》, Journal of Dalian Education Academy 《大连教育学院 学报》, 1994 (01).

16 Yan Tingjun 颜廷军: "Discussion on Wang Shifu's Absent of Four Great Scholars in Yuan Drama" 《王实甫不入“元曲四大家”原因管窥》, Journal of Lianyungang Vocational and Technical College (Comprehensive Edition) 《连云港 职业技术学院学报》(综合版), 2006 (01).

$17 \mathrm{Xu}$ Shuai 徐帅: "Reasons for Speculation on Wang Shifu's Absent of Four Great Scholars in Yuan Drama" 《元曲四大家无王实甫原因臆测》, Cultural and Educational Materials《文教资料》，2006 (15). 
four-fold, it is not the Mo but Mo..... This is also true. Otherwise, there are exceptions..... Dan is not enough for embellishment to break the example of Yuan drama, but there were still special cases. Only the fourth fold of the first, fourth and fifth performances in Romance of the Western Chamber were sung by two persons.

元剧每折唱者, 止限一人, 若末若旦; 他色则有白无唱。 若唱, 则限于楔子中; 至四折中之唱者, 则非末若旦不 可......此一定例也。然亦有出于例外者......盖旦以供点缀 之用, 不足破元剧之例也。唯《西厢记》第一、第四、第 五剧之第四折，皆以二人唱。1 18

Therefore, Romance of the West Chamber is more similar to the southern drama and even the Chuanqi system.

However, this cannot be regarded as the real reason why Wang Shifu failed to enter the "four great scholars of Yuan drama". Zhou Deqing's comments did not show that Wang Shifu was not important in Yuan dynasty. Actually, Romance of the West Chamber was an excellent drama in the Yuan dynasty. What really makes Wang Shifu wander in and out of the "Four great scholars" is the difference in concepts of drama theorists in Ming dynasty. [9] He Liangjun objected to Wang Shifu out of his recognition in his own literary works and who believed that the brilliant literary words in Romance of the West Chamber, were not stylistic appeal of Yuan Zaju:

If Romance of the West Chamber was rich of talented, the northern $\mathrm{Ci}$ could not be succeeded. Finally, the flesh was better than the bone. So let the Baiyue Pavilion be a place.

若《西厢》, 才华富赡, 北词大本未有能继之者, 终是 肉胜于骨, 所以让《拜月》一头地。19

In this respect, Guan Hanqing's Baiyue Pavilion had superior acrobatics skills due to he believed that "filling in words must be in the native language, and only then can it be a writer"盖填词须用本色语, 方是作家。 ${ }^{20}$ As for Wang Shizhen and other writers who advocate literary works, they pay more attention to the words in Romance of the West Chamber. [10] However, there were also different opinions, such as Xu Fuzuo's opposition to Wang Shizhen's practice, but he believed that Romance of the West Chamber was a distinctive character work:

Wang Xuzhou takes words from Romance of the West Chamber so called 'Snow Waves Beat the Sky', and also directly took their anima, the quintessence was not the same. Speaking of its wonder, words should be acted upon, and its essence can be called the champion of the north and south.

王弁州取《西厢》“雪浪拍长空”诸语, 亦直取其华艳耳, 神髓不在是也。语其神, 则字字当行, 言言本色, 可谓南 北之冠。21

Thus, it involves different perceptions of identity, while

18 Fu Dixiu 伏涤修; Fu Mengmeng 伏蒙蒙: Materials Collection on Romance of the West Chamber 《西厢记资料汇编》, Mountain Huang Book House 黄山书社, 2012, last of two volumes, p. 562.

19 Shen Defu: Baiyue Pavilion in Miscellaneous remarks of Composing Music, 《顾曲杂言·拜月亭》, Integration of Chinese Classical Dramas Works, Vol. 4, p. 210 .

20 He Liangjun: Siyou Zhai Anthology, vol. 37.

21 Xu Fuzuo 徐复祚: Tune Discussion 《曲论》, Integration of Chinese Classical Dramas Works, Vol. 4, p. 210.
Romance of the West Chamber becomes a carrier, providing a case for the theoretical cognition of dramatists. As a result, not only did Wang Shifu once become a member of the "four great scholars", but he also achieved classical status of Zaju Romance of the West Chamber and became the "ancestor of northern tune" and "forbear of drama and text", for example, Liu Tingji's Miscellaneous remarks of Zai Garden:

From ancient times to now, every $\mathrm{Ci}$-writer had taken the Story of Pipa as $\mathrm{Zu}$ 祖, and Romance of the West Chamber as Zong 宗, and there were no others who have gone up to the same level.

自古迄今, 凡填词家咸以《琵琶》为祖, 《西厢》为宗, 更无有等而上之者。22

\section{Conclusion}

In a word, Wang Shifu was absent in the "four great scholars of Yuan drama", which did not mean that he was excluded from Yuan drama. The attention and evaluation of Wang Shifu's Romance of the West Chamber by the Dramas critics in past dynasties are evident. In Ming and Qing dynasties, Tang Xianzu's Peony Pavilion 《牡丹亭》and Cao Xueqin's 曹雪芹 A Dream of Red Mansions 《红楼梦》were obviously influenced by Romance of the West Chamber. There are no less than a hundred kinds of engraved scripts in Ming and Qing Dynasties, which were the best-selling drama scripts at present. Romance of the West Chamber had also been translated into many languages and spread abroad, and its outstanding achievements in Dramas creation had also produced great repercussions abroad. In all these ways, Wang Shifu's Romance of the West Chamber is indeed the "worldly top".

\section{References}

[1] Du Juan: "The Adaptation and Inheritance of Beijing Opera The Story of the West Chamber", Jingju of China, vol. 9, 2018.

[2] Yang Xurong: "A Research into Ji zhi zhai Edition of Readjustment of the North Western Chamber", Jianghuai Tribune, vol. 5, 2018.

[3] Lv Mengyun: "An Analysis of the Main Female Characters in The Story of the Western Chamber", Culture Journal, vol. 10, 2018.

[4] Gao Yanyi: Boudoir Teacher: Female literati culture in Jiangnan District during the Late Ming and Early Qing Dynasties, Jiangsu People's Publishing House, 2005.

[5] J. Richard Udry: The Nature of Gender, Demography, Nov. 1994, p. 561.

[6] Hu Shi: Women Authors in three hundred years, Collection of Hu Shi's Works, Yuanliu Publishing Company Limited, 1996, vol. 14.

22 Liu Tingji 刘廷现: Miscellaneous remarks of Zai Garden《在园杂志》, $54^{\text {th }}$ year of Kangxi in Qing dynasty 清康熙五十四年刻本, Vol. 3. 
[7] Tan Tian Yuan: "Qu Writing in Literati Communities Rediscovering Sanqu Songs and Drama in Sixteenth-century North China", Harvard University, PhD thesis, 2006.

[8] Sophie Volpp: Worldly Stage: Theatricality in Seventeenth-Century China, Harvard: Harvard University Asia Center, 2011.
[9] Mark Stevenson\&. Wu Cuncun: Homoeroticism in Imperial China: A Sourcebook, New York: Routledge, 2013.

[10] Chen Xingyao: "A Comparative Study of Two English Versions of Xi Xiang Ji from the Perspective of Rewriting Theory", Chongqing Normal University, Master thesis, 2018. 